\title{
Flooding and Household Preparedness in Benin City, Nigeria
}

\author{
Ezemonye, Mary. $\mathrm{N}$ \\ Department of Geography and Regional Planning, \\ University of Benin, Benin City, Nigeria \\ E-mail: ezemonyemary@yahoo.com,
}

\section{Emeribe, Chukwudi. N}

Environmental Pollution and Remediation, National Centre for Energy and Environment, University of Benin, Benin city

\section{Doi:10.5901/mjss.2014.v5n1p547}

\section{Abstract}

Flooding is a major environmental hazard in Nigerian urban centers that has defiled solution. The vulnerable nature of these urban centers is compounded by the tropical climate, rapid deforestation, unplanned growth, non-engineered constructions coupled with encroachment on flood prone areas. Flood disasters are major threats to human-beings and reverse major developmental processes in any locality, hampering socio/economic activities. Household preparedness mitigates the impacts of flood on vulnerable populations. Preparedness and mitigation phases occur as improvements are made in anticipation of flood disasters. Thus household ability to prepare for flood disasters is very crucial in the immediate response and long-term recovery phases. The paper examined Disaster Risk Reduction (DRR) in the light of household preparedness in Benin City, Nigeria. The study's findings confirm that there is no household preparedness in relation to flood and $95 \%$ of the respondents indicated that their religious believe system is a major governing factor to the none utilization of preparedness as a response to any disaster. The ANOVA test shows that there is a significant difference among households in terms of their flood disaster preparedness. A multiple correlation analysis indicated that religious belief and lack of funds determine household preparedness as these two variables explain the highest variance in the socio economic factors influencing utilization of flood disaster preparedness measures. The study recommends the exploration of household preparedness as first mitigation strategy in the light of the hopeless nature exhibited by households in events of flood disasters. Sensitization of households on the need for saving money towards ameliorating flood impact is needed while strengthening institutional preparedness targeted at disaster risk reduction.

Keywords: Flooding, Disaster Risk Reduction, Environmental Hazard, Household Preparedness, Mitigation Strategy, Institutional Preparedness.

\section{Introduction}

People the world over are experiencing different forms of natural hazards and are affected by these hazards at regular intervals that are unpredictable. Natural hazards according to Burton, Kates and White (1978) are those elements of the physical environment, harmful to man and caused by forces extraneous to him. Olorunfemi and Raheem (2008) are of the opinion that it is a potential event or human activity which may cause the loss of life or injury, property damage, social and economic disruption or environmental degradation. A hazard therefore refers to the potential occurrence, in a specific time period and geographic area of a natural phenomenon that may adversely affect human life, property or activity. Potentially hazardous natural phenomena could be classified as atmospheric, seismic, hydrologic, volcanic and wild fire. Flood falls into the category of hydrologic hazards and Sinnakordan et al (2003) are of the opinion that a flood event can be regarded as a hazard if it has the potential of causing a threat to humans and their welfare.

The term flood is variously defined and used: the European Union (2007) defined flood as a temporary covering by water of land not normally covered by water. A more agreeable definition depicting what floods entail is Chow's (1956) definition that specifies that it is a relatively high flow which oversteps the natural channel provided for the runoff. It is a natural response of a river or stream or mere drainage valley/channel that has too much water to cope with (Aderogba, 2012). Floods are the most reoccurring, widespread, disastrous and frequent natural hazards of the world. (Odufuwa et al 2012). 
Natural factors are often the main cause of floods although other factors such as anthropogenic factors (such as occupation/settlement in flood plains, extensive urbanization, basin wide landuse changes and structural measures) have modified the natural characteristics worldwide (Turner et al, 1993, Boyle et al. 1997, Weng, 2001, Odjugo et al. 2006; Ezemonye and Emeribe, 2011). It is also noteworthy that rapid growth of world population and its increased concentration often in hazardous places has escalated both the frequency and severity of natural disasters. Any flood that affects any populated area is considered to be a disaster. UNISDR (2008) defined a disaster as serious disruption of the functioning of a community or society causing widespread human, material, economic/social and environmental losses which exceed the ability of the affected community or society to cope using its own resources. They are repeated events that may strike at random but impact on both the rate and pattern of development (Arriens and Benson, 1999). Disasters are intensified usually by vulnerability thus they affect the world's poorest the most. UNDP (2004) described vulnerability as the conditions determined by physical, social, economic and environmental factors or processes which increase the susceptibility of a community/nation to the impacts of Hazards.

Noji and Lee (2005) are of the opinion that flood disasters are most widespread and occur in countries, causing most deaths. It also takes its toll on properties, the vulnerable and underprivileged. Flood disasters derail socio-economic progress and intensify poverty by making the poor even poorer. Thus the marked difference as regards vulnerability to flooding arises usually from wide gaps in access to resources and capacity for disaster risk reduction associated with poverty and socio-cultural stratification. Disaster management is a cyclical process; the end of one phase is the beginning of another Fig. 1. However one phase of the cycle does not need to be completed before the next can take place.

Figure 2: Disaster management cycle (Source: Garatwa \& Bollin, 2002)

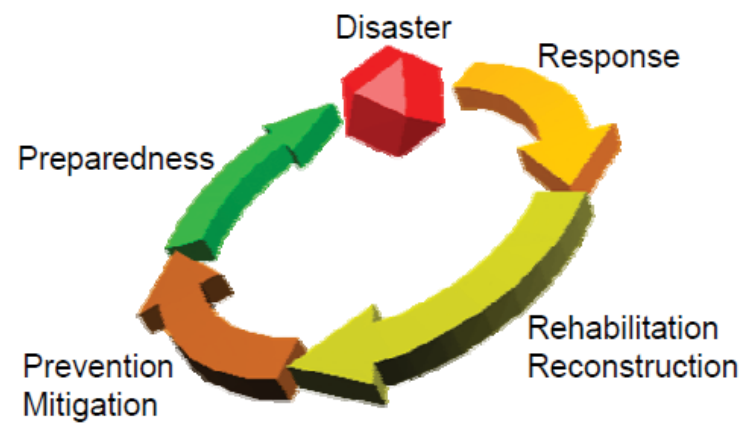

MunichRe (2005) specified that economic damage caused by urban floods is rising. In Nigeria, many marked flood disasters have occurred in her urban areas with 2012 occurrence heightening the need for flood management. Aderogba (2012) in his study of 25 cities/towns in Nigeria, identified the frequency and duration of floods. The study indicated that Benin City experiences flood duration that last up to 10 days and mean lowest rain duration of 12 days. The high frequency coupled with urbanization aggravates flooding extensively by restricting where flood water can flow (Ojigi et al, 2013). In most cases, the devastation caused by urban floods especially on households is usually a reflection of their lack of preparedness. According to IFRC, (2007), none preparedness, poor and low budgetary allocation for disaster prevention in developing countries make them experience greatly the impacts of natural disaster. No country is immuned to flooding and the impacts are heightened by lack of capacity and preparedness.

Hazards cannot be prevented from occurring especially natural hazards such as flooding but the vulnerability associated with flood disaster can be mitigated by one aspect of disaster management: preparedness. Preparedness action is closely related to how individuals perceive and act on risk information (Tierney et al 2001). Preparedness measures have the big advantage of being able to address root causes and dynamic pressures instead of symptoms in a system, which is more stable than after a disaster (Enenkel, 2010). It is also true that no two flood events and disasters are exactly the same, but the many aspects of the full life cycle of disaster management can help mitigate a flood disaster. Flood preparedness plan (FPP) for households is about putting in place a set of appropriate arrangements in advance for an effective response to floods. This is an important phase of flood disaster management which is almost being neglected in developing countries. There is a tendency to rely more on what the government can do while neglecting self-help options. Thus disaster risk reduction measures that reduce the vulnerability of households to flood 
disasters are advocated for in view of the fact that the cost implication of recovery and rehabilitation measures are enormous compared to preventive strategies such as preparedness actions.

\section{Research Methodology}

The study was conducted from 2011- 2012, in Benin City, Edo State, Nigeria. The year 2011 was devoted to understanding the underlying factors related to flooding and human habitations plus the flood prone areas and the pattern of flooding. Both field work, primary and secondary data were used for the study. Primary data was obtained through the administration of structured questionnaires and utilization of oral interviews where necessary. The questionnaire was made up of 34 structured close and open ended questions to enable the freedom of expression and ensure uniformity of responses. The questions cover socio-economic status, preparedness ascertaining issues and reasons for non utilization of preparedness as mitigation option. Purposive sampling method was adopted in the study to selected flood disaster preparedness measures practiced by flood prone households. McMillan and Schumacher (1997) describe purposive sampling as "selecting information-rich cases for study in-depth" when one wants to understand something about those cases without needing or desiring to generalize to all cases. In this technique, the researcher chooses the sample based on appropriateness for the study. The choice of this method is based on the fact that sample units have particular features or characteristics which will enable detailed exploration and understanding of the central themes and puzzles which the researcher wishes to study" (Ritchie, Lewis and Elam 2003). Locations were sought where there had been significant flooding, so that those interviewed would have been affected by flooding or were likely to have some awareness of the event in what might be considered their "local community".

Flood prone areas were identified during the rainy season/flooding period of 2011. The areas utilized for this study are flood endemic streets in Ugbowo, Uselu, Urubi, Oliha and Ogbelaka Quarters. Households that annually experience flooding and still reside in these quarters were selected for the study. Using a stratified random sampling technique houses to be sampled were selected and only heads of households (male or female) qualified for the study. A total of 500 questionnaires were administered, 100 questionnaires per sample location. In addition, a three-point Likert-type scale was adopted. Studies have shown that Likert scales can indeed be analyzed effectively as interval scales (Baggaley and Hull, 1983; Maurer and Pierce, 1998; and Vickers, 1999).

Data collected from the field were subjected to various parametric statistical analyses. The Pearson Product moment correlation ( $r$ ) was used to evaluate the relationship between household preparedness and influencing socioeconomic variables of the households. To determine the extent of spatial variation in household preparedness for flooding, a one way single factor Analysis of Variance (ANOVA) was utilized. A multiple correlation was used to describe the relationship between household preparedness and the independent variables (measured as factors indicating response to flooding). All quantitative statistics were performed using Statistical Package for Social Science (SPSS) Version 16.0.

\section{Study area}

Benin City is the capital of Edo state, Nigeria. It is located within Latitude $6^{\circ} 44^{\prime} \mathrm{N}$ and $6^{\circ} 21^{\prime} \mathrm{N}$ and Longitude $5^{\circ} 35^{\prime} \mathrm{E}$ and $5^{\circ} 44^{\prime} \mathrm{E}$ (Fig 1). The area is about $1125 \mathrm{~km}^{2}$. Benin is situated on fairly flat land, about $8.5 \mathrm{~km}$ above sea level so it is a flat terrain. It lies in the thick equatorial rainforest zone which experiences heavy rainfall. Between November and March a relatively dry season is experienced and between April and October a very wet season occurs. Continuous rainfall days ranging from 10- 12 days are often experienced in Benin. Average rainfall between $2000 \mathrm{~mm}-2500 \mathrm{~mm}$ occurs with a mean monthly temperature of $28^{\circ} \mathrm{C}$. The city is well drained by two major rivers-lkpoba river which drains the Northeast of the city and Ogba river which drains the southwest of the city. The vegetation is predominantly the evergreen rainforest but urban development has drastically reduced the vegetation.

Many socio-economic activities are carried in Benin City and these include primary, secondary and tertiary activities (dominated by government in the formal sector and trading in the informal sector. The notable economic activities include brass casting, wood carving and blacksmith. Major markets are located within Benin city namely Oba , New Benin, Oliha, Use, Agbado and Edaiken markets. It is also a place known for its cultural integrity spanning from the time of the Ogiso dynasty (first dynasty) to the present Oba. 


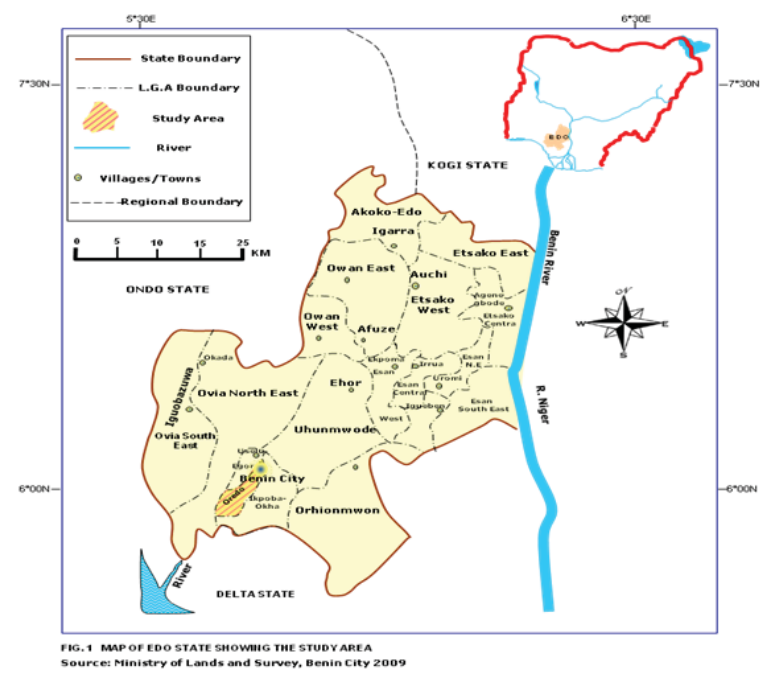

\section{Results}

Table 1 shows that of the 500 respondents, 95\% (575 respondents) indicated that they do not prepare for flooding before flooding season begins. They tend to depend more on taking actions only during lafter the flood, practicing reconstruction/rehabilitation measures. Only 5\% (25 respondents) indicated that they practice some form of preparedness before the onset of flooding period which is usually synonymous with the rainy season.

Table 1: Number of households that prepare for flooding before the flooding season.

\begin{tabular}{|c|c|c|c|}
\hline $\begin{array}{c}\text { Residential } \\
\text { quarters }\end{array}$ & $\begin{array}{c}\text { Number of households } \\
\text { sampled }\end{array}$ & $\begin{array}{c}|c| \\
\text { Regative responses (Do not } \\
\text { practice preparedness) }\end{array}$ & $\begin{array}{c}\text { Positive responses (Do practice } \\
\text { preparedness) }\end{array}$ \\
\hline Oliha & 100 & 100 & 0 \\
\hline Ogbelaka & 100 & 100 & 0 \\
\hline Urubi & 100 & 100 & 0 \\
\hline Uselu & 100 & 100 & 10 \\
\hline Ugbow0 & 100 & 75 & 25 \\
\hline Total & 500 & 475 & $5 \%$ \\
\hline Percentage & & $95 \%$ & \\
\hline
\end{tabular}

It was deciphered from the study that the households' reasons for not practicing flood preparedness as mitigation measure against flood disaster varied as shown in table 2. From table 2, it is observable that $95 \%$ of the respondents do not prepare for flood due to their religious beliefs. They perceive flooding as a natural event that is "an act of God" and preparing for it amounts to not having faith that their creator can protect them nor avert disaster occurrence.

Table 2: Factors that militate against the practice of preparedness in Benin City

\begin{tabular}{|c|c|c|c|c|}
\hline \multirow{2}{*}{ Residential quarters } & \multicolumn{5}{l}{ Factors that militate against the practice of preparedness as mitigation measure ( Percentage Response pattern) } \\
\cline { 2 - 5 } & Lack of funds & Religious belief & Reliance on government & Literacy level \\
\hline Oliha & $24 \%$ & $22 \%$ & $19.2 \%$ & $5.8 \%$ \\
\hline Ogbelaka & $16.4 \%$ & $18 \%$ & $20 \%$ & $6.4 \%$ \\
\hline Urubi & $19.6 \%$ & $16.2 \%$ & $20 \%$ & $5.2 \%$ \\
\hline Uselu & $10 \%$ & $18 \%$ & $14.4 \%$ & $0.6 \%$ \\
\hline Ugbowo & $16.4 \%$ & $20.8 \%$ & $9.4 \%$ & $2.0 \%$ \\
\hline Total percentage & $86.4 \%$ & $95 \%$ & $83 \%$ & $20 \%$ \\
\hline
\end{tabular}


On the other hand, $86 \%$ of the respondents attributed lack of funds as the second militating factor. Reliance on government programmes (83\%) was identified as the third militating factor while literacy (educational level) was the least militating factor against the practice of preparedness. This shows that in spite of the high literacy level observed in the study area, religious belief and availability of personal funds were major factors controlling actions taken by households even when the households are aware of expected actions to be taken and impacts of flooding when it occurs.

The reasons identified by households residing in various quarters of Benin as militating factors varied as shown in Figure 2. The spatial variation identified shows that in Oliha quarters, lack of funds is the major militating factor, while literacy level is the least militating factor. For Ogbelaka quarter, households indicated that the major controlling factor is reliance on government programmes. Lack of funds and reliance on government programmes were identified by households in Urubi quaters as the militating factors, while religious believe is the major factor in Uselu and Ugbowo quarters.

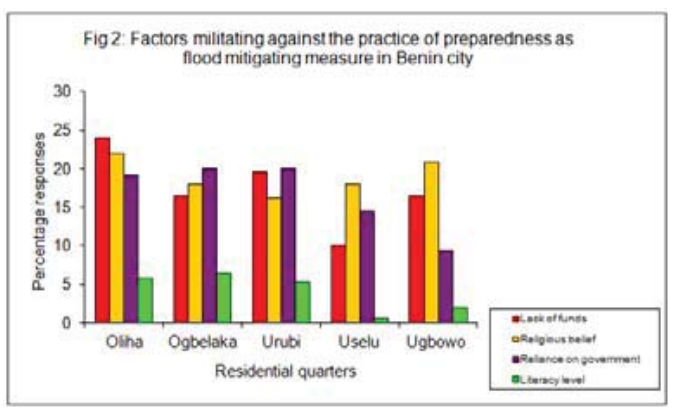

It was hypothesized that there is no significant difference among households in terms of their utilization of preparedness as flood mitigation measure. To test the hypothesis, an ANOVA test was conducted; the ANOVA test yielded an F value of 0.48 (table 3). This calculated value since the calculated F-value of 4.83 is greater than the critical $F$ value of 2.12 ie $(4.83<2.12)$ so we rejected our hypothesis. Thus there is some significant difference among households in terms of their utilization of preparedness as flood mitigation measure.

Table 3: Analysis of variance of Household flood preparedness measures

\begin{tabular}{|c|c|c|c|c|c|c|}
\hline Source of Variation & SS & df & MS & F & P-value & F crit \\
\hline Between Groups & 2903.92 & 9 & 322.6578 & 4.833824 & 0.000215 & 2.124029 \\
\hline Within Groups & 2670 & 40 & 66.75 & & & \\
\hline Total & 5573.92 & 49 & & & & \\
\hline
\end{tabular}

A multiple correlation was used to ascertain the degree of association between utilizing preparedness as mitigation measure and our four factors (lack of funds, religious belief, reliance on government programmes and literacy level) (Table 4). The influence of religious belief yielded coefficient of determination of $\mathrm{R}^{2}=0.903$, accounting for $90.3 \%$ variance in the dependent variable; a very strong positive relationship. Lack of funds for provision of flood mitigation measures accounts for $57 \%\left(R^{2}=0.577\right)$ variance in the dependent variable. Reliance on government programmes and literacy level account for $32 \%$ and $0.05 \%$ variance in the dependent variable respectively.

Table 4: Deterministic relationship between ability to plan for flood and the responsible factors.

\begin{tabular}{|l|c|c|}
\hline \multicolumn{1}{|c|}{ Pearson Correlation } & \multicolumn{2}{c|}{ Response to Non Flood Disaster Plan (As response factor) } \\
\hline Religious Belief & 0.949 & 0.903 \\
\hline Lack of funds & 0.571 & 0.325 \\
\hline Reliance on government programmes & 0.758 & 0.577 \\
\hline Literacy Level & 0.22 & 0.05 \\
\hline
\end{tabular}

From table 4, the effect of literacy on household ability to plan for flood before they occur is insignificant when compared with the effects of religious belief, lack of funds, and reliance on government programmes.

To determine the preparedness measures commonly practiced by households in Benin City, respondents were 
asked to identify preparedness measures they practice from a list of 10 likely actions (each respondent picked more than one choice). This is shown as Table 5. From table 5, the household responses show that households that never practice these preparedness measures range from $83 \%$ to $94 \%$; those who sometimes practice these measures range from $0.2 \%$ to $4 \%$ while those that always practice these measures range from $0 \%$ to $2 \%$ reconfirming the fact that preparedness is not a common flood mitigation measure practiced in Benin City.

Table 5: Selected Preparedness measures practiced by flood prone households in Benin City.

\begin{tabular}{|l|c|c|c|}
\hline \multicolumn{1}{|c|}{ Preparedness measures } & $\begin{array}{c}\text { Never } \\
\text { practiced }\end{array}$ & $\begin{array}{c}\text { Sometimes } \\
\text { practiced }\end{array}$ & $\begin{array}{c}\text { Always } \\
\text { practiced }\end{array}$ \\
\hline $\begin{array}{l}\text { Have a separate savings account for flood } \\
\text { emergency/disaster? }\end{array}$ & $470(94 \%)$ & 20 & 10 \\
$(4 \%)$ & $(2 \%)$ \\
\hline Have a family flood disaster plan? & 492 & 5 & 3 \\
\hline Plan of where household is to meet if flood & $(98.04 \%)$ & $(1 \%)$ & $(0.6 \%)$ \\
disaster occurred and you are not together? & $(86.4 \%)$ & 53 & 15 \\
\hline Plan of how to search for missing household & 470 & $(10.6 \%)$ & $(3 \%)$ \\
members & $(94 \%)$ & $(5 \%)$ & 5 \\
\hline Members of your household know each other's & 415 & 60 & $(1 \%)$ \\
phone numbers off heart? & $(83 \%)$ & $(12 \%)$ & $(5 \%)$ \\
\hline Raised the foundation of the house above flood & 488 & 10 & 2 \\
level? & $(97.6 \%)$ & $(2 \%)$ & $(0.4 \%)$ \\
\hline Have taught the little children to call emergency & 480 & 20 & 0 \\
number & $(96 \%)$ & $(4 \%)$ & $(0 \%)$ \\
\hline Insured the house against flood disaster? & 490 & 9 & 1 \\
\hline Regularly conduct a house hazard hunt to & $(98 \%)$ & $(1.8 \%)$ & $(0.2 \%)$ \\
familiarize the household & 493 & 7 & 0 \\
\hline Provision of medical kit for disaster emergences & $(98.6 \%)$ & $(1.4 \%)$ & $(0 \%)$ \\
\hline
\end{tabular}

\section{Conclusion and Recommendations}

Even though preparedness as a flood mitigation measure is an effective flood disaster mitigation measure, it is hardly practices by households in areas identified to be flood prone in Benin City. Rather the households depend more on reconstruction and rehabilitation which are capital intense measures and actions taken in most cases after the flood has had devastating effect on the populace. Household religious belief militates against self help efforts that would serve as preparedness action, thus increasing their vulnerability to flooding. Lack of funds and inability of households to save towards flood disaster makes this measure unattractive to households' in spite of being aware of the benefits inherent in utilizing the mitigation measure. Household/community preparedness can reduce the impact of flood disasters especially for the most vulnerable in flood prone areas. This mitigation measure should therefore be encouraged as the first mitigation measure in any urban centre. This study recommends as follows:

1. Generally there is a great need to create awareness among the populace that flood mitigation is not the responsibility of the government alone and also de-emphasize taking action only after the flooding has occurred,.

2. The erroneous idea that flood is "an act of god" and any preparedness measure to mitigate this amounts to exhibition of lack of faith needs to be addressed through creating awareness utilizing education achievable through conferences, media, religious activities etc.

3. Educating the people on preparedness measures that they can practice before the onset of the flooding season.

4. Environmental policy reforms that aid reduction of flood disaster vulnerability need to be introduced

5. Government assisted/controlled flood insurance, saving/loan schemes need to be introduced. The saving/loan scheme should be made flexible to encourage household participation at all levels. 


\section{References}

Aderogba K. A ( 2012): Qualitative Studies of Recent Floods and Sustainable Growth and Development of Cities and Towns in Nigeria International Journal of Academic Research in Economics and Management Sciences, Vol. 1, No. 3 pp 200-216

Arriens, W.T.L, and Benson, C. (1999): Post-Disaster Rehabilitation; The Experience of the Asian Development

Baggaley, A., and Hull, A. (1983): The effect of nonlinear transformations on a Likert scale. Evaluation \& the Health Professions, 6 , 483491.

Boyle, C.A., Lavkulich, L., Schreier, H. and Kiss, E., 1997, Changing in land cover and subsequent effects on lower Fraser basin ecosystems from 1827 to 1990, Environmental Management, 21(2), 185-196.

Burton, I. R., Kates, W. and White (1978): The Environment as Hazard. Oxford University Press, New York.

Chow, V.T. (1956): Hydrologic Studies of Floods in the United States, International Association of Scientific Hydrology Publication, vol 42, pp134-170.

Enenkel, M.(2010): Optimisation of Water-Related Preparedness measures-Case Study: Floods in Tanzania. Diploma Thesis. Natural Resources Management and Ecological Engineering Institute of Sanitary Engineering and Water Pollution Control of the University of Natural Resources and Applied Life Science, Vienna.

Ezemonye M.N and Emeribe C.N (2011): Flood Characteristics and Management Adaptations in Parts of the Imo River System Ethiopian Journal of Environmental Studies and Management Vol. 4 No.3 Pp. 112-122

Garatwa, W. \& Bollin, C. 2002. Disaster risk management. A working concept. Deutsche

Gesellschaft fur, O.K. KOPIE, Gmbit, Eschborn [Online]. Retrieved from www.gtz.de (26/10/2011).

IFRC (2007): World Disaster Report. Geneva: International Federation of Red Cross and Red Cresent Societies. www. ifrg.org/publicat/wdr/2006

International Strategy for Disaster Reduction (ISDR) (2002): Living with Risk: A global Reviews of Disaster Reduction Initiatives. PreliminaryVersion. Geneva: ISDR Secretariat.

Maurer, J., \& Pierce, H. R. (1998). A comparison of Likert scale and traditional measures of self-efficacy. Journal of Applied Psychology, 83, 324-329.

McMillan, J.H. and Schumacher, S. (1997): Research in education: A conceptual introduction.4th ed. New York: Longman.

MunichRe (2005): Megacities: Trends and challenges for Insurances and Risk Management,http://www.munichre.com/publications/30204271 en.pdf

Niekerk, D. (2002): Disasters and Sustainable Development. African Center for Disaster studies. Potchefstroom University, South Africa.

Noji, E.K. and Lee, C.Y.(2005): Disaster Preparedness in Frumkin,H(ed) Environmental health:from Global to Local. Jossey-Bass press, San Francisco, CA.

Odufuwa, B.O., Adedeji, O.H., Oladesu, J.O, Bongwa, A. (2012): Floods of fury in Nigerian cities. Journal of Sustainable Development. vol 5, no 7, pp 69-79.

Odjugo PAO, Iweka DE (2006): The Impact of Urbanization on microclimates: A case study of Benin City, Nigeria. J. Environ. Sci., 10(1): 80.

Ojigi, M.L, Abdulkadir, F.I. and Aderogu, M.O.(2013): geospatial Mapping and Analysis of the 2012 flood Disaster in Central Parts of Nigeria. $8^{\text {th }}$ National GIS Symposium, Damma, Saudi Arabia. April 15-17, 2013.

Olorunfemi, F.B. and Raheem, U.(2008): Sustainable Disaster Risk Reduction In Nigeria: Lessons for Devloping Countries. African Research Review, 2(2), pp187-217.

Ritchie, L. Lewis, J. \& Elam, G. (2003): Designing and Selecting Samples in Ritchie, J. \& Lewis, J. (eds.) (2003) Qualitative Research Practice: A Guide for Social Science Students and Researchers. London: Sage publications pp. 77-108

Tierney,K.T., Lindell, M.K., Perry,R.W.(2001): Facing Hazards and disasters:Understanding Human Dimensions. Joseph Henry Press

Turner, B.L., Moss, R.H. and Skole, D.L. (eds.), (1993): Relating Landuse and Global Land-Cover Change: A Proposal for an IGBP-HDP Core Project, Global Change Report, IGBP Report No. 24, HDP Report No. 5, Stockholm, Sweden.

Sinnakordan, S.K., Ghani, A.A., Ahmad, M.S.S., Zakaria, N.A.(2003): Flood Risk Mapping for Pari River incorporating sediment Transport. Journal of Environmental Modelling and Software, vol 18,no 2, pp119-130

Uitto, J.I. (1998): The geography of disaster vulnerability in Megacities: A theoretical Framework, Applied Geography, vol 18, no 1, pp716.

UNDP (2004): Reducing Disaster Risk: A challenge for Development, A global Report UNDP.

UNDP (2004): Reducing Disaster Risk: A Challenge for Development, A Global Report UNDP

UN-International Strategy for Disaster Reduction (UN-ISDR) (2008): "Disaster Risk Reduction Strategies and Risk Management Practices: Critical Elements for Adaptation to Climate Change" Submission to the UNFCCC Adhoc Working Group on Long Term Cooperative Action. Available at: www.unisdr.org/.../risk- reduction/climatechange/.../IASC- ISDR_paper_cc_and_DDR.pdf (Accessed 16 Oct. 2011).

Vickers, A., (1999): Comparison of an ordinal and a continuous outcome measure of muscle soreness. International Journal of Technology Assessment in Health Care, 15, 709-716.

Weng, Q., (2001): Modeling urban growth effects on surface runoff with integration of remote sensing and GIS, Environmental Management, 28(6), 737-748. 
